\title{
HUBUNGAN PENGETAHUAN DAN SIKAP TERHADAP KEPATUHAN MINUM OBAT PASIEN TUBERKULOSIS PARU FASE LANJUTAN DI KECAMATAN UMBULSARI JEMBER
}

\author{
The Correlation between Knowledge and Attitude towards the Adherence of \\ Medication in Tuberkulosis Pulmonary Patient on \\ Continuation Phase in Umbulsari Jember
}

\author{
${ }^{1}$ Elita Ismi Mientarini, ${ }^{2}$ Yohanes Sudarmanto, ${ }^{3} \mathrm{M}$. Hasan \\ ${ }^{123}$ Fakultas Kedokteran Universitas Jember \\ Jl. Kalimantan 37, Jember 68121 \\ e-mail: litaismi53@gmail.com
}

\begin{abstract}
Tuberkulosis (TB) is a infectious disease caused by $t$ Mycobacterium Tuberculosis. Indonesia is the second country with highest number of TB cases in the world after India. Medication adherence is essential for successful TB treatment. One of the factors that can influence someone adherence to TB treatment is knowledge and attitude. This study aimed to know the correlation between knowledge and attitude towards the adherence of medication in tuberkulosis pulmonary patient on continuation phase in umbulsari jember. This study was an obsevational analytic using cross sectional with total sample technique method. Data were obtained through questionnaire (knowledge questionnaire, $H R H S$, and MMAS-8) then analyzed with Spearman correlation test $(p=<0,05)$. The results showed a significant between compliance with knowledge at the level of know with the value of $p=0.041$. While the results of the correlation of compliance with knowledge at the level of understanding and application and between attitudes and compliance obtained results not signifikan.
\end{abstract}

Keyword : Continuation Phase, Medication Adherence, Knowledge, Attitude

\begin{abstract}
Abstrak
Penyakit Tuberkulosis (TB) merupakan penyakit menular yang disebabkan oleh bakteri Mycobacterium Tuberkulosis. Indonesia menempati peringkat kedua setelah India dengan jumlah kasus TB terbanyak di dunia. Kunci keberhasilan pengobatan TB adalah kepatuhan pasien dalam mengkonsumsi obat. Salah satu faktor yang dapat mempengaruhi perilaku seseorang dalam mematuhi anjuran berobat adalah pengetahuan dan sikap. Tujuan penelitian ini adalah mengetahui hubungan antara pengetahuan dan sikap terhadap kepatuhan minum obat pasien Tuberkulosis Paru pada pase lanjutan di Kecamatan Umbulsari Jember. Metode penelitian yang digunakan adalah analitik observasional dengan pendekatan cross sectional. Sumber data didapatkan melalui pengisian kuesioner pengetahuan, HRHS, dan MMAS-8 kemudian data dianalisis dengan menggunakan uji korelasi Spearman $(\mathrm{p}=0,05)$. Hasil penelitian menunjukkan hasil yang siginifkan antara kepatuhan dengan pengetahuan pada level tahu dengan nilai $p=0,041$.

123 Elita Ismi Mientarini, Yohanes Sudarmanto, dan M. Hasan adalah Fakultas Kedokteran Universitas Jember
\end{abstract}


Sedangkan hasil korelasi kepatuhan dengan pegetahuan pada level memahami dan aplikasi maupun antara sikap dan kepatuhan didapatkan hasil tidak signifikan.

Kata kunci: Fase Lanjutan, Kepatuhan, Pengetahuan, Sikap

\section{PENDAHULUAN}

Penyakit tuberkulosis merupakan penyakit menular langsung yang disebabkan oleh kuman Mycobacterium tuberculosis. Jumlah pasien TB paru terkonfirmasi di Indonesia mengalami peningkatan signifikan dari tahun 2008 hingga puncaknya pada tahun 2011. World Health Organization merilis bahwa pada tahun 2015, Indonesia menduduki peringkat kedua setelah India dengan penderita TB terbesar di dunia. [1]

Setelah seseorang terdiagnosis TB, maka dilanjutkan dengan melakukan serangkaian pengobatan TB yang terdiri dari fase intensif selama dua bulan petama dan fase lanjutan selama empat bulan berikutnya. Lamanya masa pengobatan tersebut dapat menyebabkan kejenuhan bagi pasien dan menjadi salah satu faktor yang akan mempengaruhi tingkat kepatuhan pasien dalam mengonsumsi obat.[2] Pada umumnya pasien yang memasuki fase lanjutan seolah merasa sembuh kemudian menghentikan pengobatannya.[3]

Pengetahuan dinilai sangat penting untuk keberhasilan pengobatan TB karena pasien akan mendapatkan informasi mengenai cara penularan, tahapan pengobatan, tujuan pengobatan, efek samping obat, dan komplikasi penyakit. Pengetahuan yang dimiliki seseorang tersebut akan mempengaruhi bagaimana ia bersikap, berencana, dan mengambil keputusan. [4]
Tujuan penelitian ini adalah untuk mengetahui hubungan antara pengetahuan dan sikap terhadap kepatuhan minum obat khususnya di Kecamatan Umbulsari Jember sebagai kecamatan dengan angka kejadian TB tertinggi di Kabupaten Jember periode Januari-Juni 2017. Hipotesis dari penelitian ini adalah terdapat hubungan yang signifikan antara pengetahuan dan sikap terhadap kepatuhan minum obat pasien TB paru fase lanjutan.

\section{METODE PENELITIAN}

Jenis penelitian ini adalah penelitian analitik observasional dengan pendekatan cross sectional. Penelitian ini dilaksanakan di UPTD layanan kesehatan Puskesmas Umbulsari dan Puskesmas Paleran pada 30 November - 26 Desember 2017. Teknik penentuan sampel yang digunakan adalah total sampling, dimana seluruh populasi yang memenuhi kriteria inklusi dan eksklusi akan dijadikan sampel.

Instrumen penelitian yang digunakan adalah Kuesioner Pengetahuan Umum TB untuk menilai pengetahuan pasien mengenai TB Paru, kuesioner Health Related Hardiness Scale (HRHS) untuk menilai sikap yang dimiliki sampel, dan kuesioner Morisky Medication Adherence Scale (MMAS-8) untuk menilai kepatuhan minum obat. Analisis data pada penelitian ini mengunakan uji korelasi Spearman untuk mengetahui hubungan antara Pengetahuan dan sikap 
terhadap kepatuhan minum obat. Program pengolahan statistik yang digunakan adalah software SPSS versi 16.0 dengan $\mathrm{p}<0,05$.

\section{HASIL PENELITIAN}

Sampel akhir yang menenuhi kriteria inklusi dan ekslusi didapatkan sebanyak 21 sampel. Distribusi sampel berdasarkan jenis kelamin, usia, lama pengobatan yang telah dijalani, tingkat pendidikan, status pekerjaan, dukungan keluarga, tingkat keputusasaan, dan kepatuhan minum obat sampel dapat dilihat pada tabel-tabel berikut ini.

Tabel 4.1 Distribusi Karakteristik Sampel Penelitian

\begin{tabular}{lcc}
\hline Karakteristik & Jumlah (n) & $\begin{array}{c}\text { Persentase } \\
\text { (\%) }\end{array}$ \\
\hline Jenis Kelamin & 9 & 42,9 \\
Laki - laki & 12 & 57,1 \\
Perempuan & & \\
\hline Usia & 1 & 4,8 \\
13-18 tahun & 3 & 14.3 \\
18-24 tahun & 2 & 9,5 \\
24-34 tahun & 11 & 52,4 \\
34- 60 tahun & 4 & 19,0 \\
60-75 tahun & & \\
\hline Lama Pengobatan & 8 & 38,1 \\
3 bulan & 9 & 42,9 \\
4 bulan & 3 & 14,3 \\
5 bulan & 1 & 4,8 \\
6 bulan & & \\
Pendidikan Terakhir & 3 & 14,3 \\
Tidak tamat SD & 8 & 38,1 \\
SD & 4 & 19 \\
SMP & 5 & 23,8 \\
SMA & 1 & 4,8 \\
Sarjana & & \\
\hline Status Pekerjaan & 5 & 23,8 \\
Bekerja & 14 & 66,7 \\
Tidak Bekerja & 2 & 9,5 \\
Pelajar & &
\end{tabular}


Tabel 4.2 Distribusi Frekuensi Sampel Berdasarkan Tingkat pengetahuan, Sikap, dan Kepatuhan

\begin{tabular}{|c|c|c|}
\hline Karakteristik & $\begin{array}{c}\text { Jumlah } \\
\text { (n) }\end{array}$ & $\begin{array}{c}\text { Persentase } \\
\text { (\%) }\end{array}$ \\
\hline \multicolumn{3}{|l|}{ Pengetahuan } \\
\hline \multicolumn{3}{|l|}{ Tahu } \\
\hline Sangat Kurang & 1 & 4,8 \\
\hline Kurang & 7 & 33,3 \\
\hline Baik & 8 & 38,1 \\
\hline Sangat Baik & 5 & 23,8 \\
\hline \multicolumn{3}{|l|}{ Memahami } \\
\hline Sangat Kurang & 3 & 14,3 \\
\hline Kurang & 5 & 23,8 \\
\hline Baik & 9 & 42,9 \\
\hline Sangat Baik & 4 & 19,0 \\
\hline \multicolumn{3}{|l|}{ Aplikasi } \\
\hline Sangat Kurang & 0 & 0,0 \\
\hline Kurang & 3 & 14,3 \\
\hline Baik & 6 & 28,6 \\
\hline Sangat Baik & 12 & 57,7 \\
\hline \multicolumn{3}{|l|}{ Sikap } \\
\hline Baik & 8 & 38,1 \\
\hline Cukup & 13 & 61,9 \\
\hline Kurang & 0 & 4,8 \\
\hline \multicolumn{3}{|l|}{ Kepatuhan Minum Obat } \\
\hline Rendah & 1 & 4,8 \\
\hline Sedang & 7 & 33,3 \\
\hline Tinggi & 13 & 61,9 \\
\hline
\end{tabular}

Tabel 4.3 Distribusi Frekuensi Tingkat Kepatuhan Berdasarkan Pengetahuan dan Sikap

\begin{tabular}{lccc}
\hline \multicolumn{1}{c}{ Pengetahuan } & $\begin{array}{c}\text { Rendah } \\
\text { (n (\%)) }\end{array}$ & $\begin{array}{c}\text { Tingkat Kepatuhan } \\
\text { Sedang } \\
\text { (n (\%)) }\end{array}$ & $\begin{array}{c}\text { Tinggi } \\
\text { (n (\%)) }\end{array}$ \\
\hline Tahu & $0(0,0)$ & $0(0,0)$ & $1(100,0)$ \\
Sangat Kurang & $1(14,3)$ & $4(57,1)$ & $2(28,6)$ \\
Kurang & $0(0,0)$ & $3(37,5)$ & $5(62,5)$ \\
Baik & $0(0,0)$ & $0(0,0)$ & $5(100,0)$ \\
Sangat baik & & & \\
Memahami & $0(0,0)$ & $1(33,3)$ & $2(66,7)$ \\
Sangat Kurang & $1(20,0)$ & $1(20,0)$ & $3(60,0)$ \\
Kurang & $0(0,0)$ & $2(22,2)$ & $7(77,8)$ \\
Baik & $0(0,0)$ & $3(75,0)$ & $1(25,0)$ \\
Sangat baik & $0(0,0)$ & $0(0,0)$ & $0(00,0)$ \\
\hline Aplikasi & & &
\end{tabular}




\begin{tabular}{lccc}
\hline \multicolumn{1}{c}{ Pengetahuan } & $\begin{array}{c}\text { Tingkat Kepatuhan } \\
\text { (nedah }\end{array}$ & $\begin{array}{c}\text { Sedang } \\
\text { (n (\%)) }\end{array}$ & $\begin{array}{c}\text { Tinggi } \\
\text { (n (\%)) }\end{array}$ \\
\hline Kurang & $1(33,3)$ & $0(0,0)$ & $2(66,7)$ \\
Baik & $0(0,0)$ & $3(60,0)$ & $3(50,0)$ \\
Sangat baik & $0(0,0)$ & $4(30,8)$ & $8(66,7)$ \\
\hline
\end{tabular}

Tabel 4.4 Uji Korelasi Spearman antara Pengetahuan dan Kepatuhan

\begin{tabular}{lc}
\hline & Tingkat Kepatuhan \\
\hline \multirow{2}{*}{ Tingkatan Pengetahuan Level Tahu } & $\mathrm{r}=0,449$ \\
$\mathrm{p}=0,041$ \\
\hline Tingkatan Pengetahuan Level & $\mathrm{r}=-0,136$ \\
Memahami & $\mathrm{p}=0,555$ \\
\hline Tingkatan Pengetahuan Level & $\mathrm{r}=0,204$ \\
Aplikasi & $\mathrm{p}=0,375$ \\
\hline
\end{tabular}

Tabel 4.5 Uji Korelasi Spearman antara Sikap dan Kepatuhan

\begin{tabular}{lc}
\hline & Tingkat Kepatuhan \\
\hline \multirow{2}{*}{ Tingkatan Sikap } & $\mathrm{r}=0,228$ \\
& $\mathrm{p}=0,321$ \\
\hline
\end{tabular}

\section{PEMBAHASAN}

Berdasarkan hasil data yang diperoleh, sampel pada penelitian ini sebagian besar adalah perempuan. Hasil ini sejalan dengan penelitian yang dilakukan oleh Linda (2012) dan Erawatyningsih dan Purwanta (2009). [5][6] Hal ini dapat terjadi karena perempuan lebih banyak melaporkan gejala penyakitnya serta berkonsultasi dengan dokter sehingga didapatkan data dimana penderita TB Paru lebih banyak pada perempuan. [6] Sedangkan karakteristik sampe berdasarkan usia didapatkan hasil bahwa sebagian besar sampel berada pada usia produktif yaitu 15-64 tahun. Hasil ini sesuai dengan data Kemenkes (2011) yang menyatakan bahwa sekitar $75 \%$ pasien TB adalah kelompok usia produktif dikarenakan pada usia produktif seseorang cenderung mempunyai mobilitas yang tinggi sehingga resiko penularan maupun resiko untuk terpapar kuman TB lebih besar. [7]

Sedangkan pada karakteristik
sampel berdasarkan pekerjaan didapatkan hasil sebagian besar sampel tidak bekerja. Sama seperti halnya dengan pernyataan Kemenkes (2011) yang menyatakan bahwa diperkirakan seorang pasien TB dewasa akan kehilangan rata-rata waktu kerjanya 3 sampai 4 bulan dan hal tersebut berakibat pada kehilangan pendapatan tahunan rumah tangganya sekitar 20$30 \%$. [7] Sedangkan berdasarkan karakteristik pendidikan, sampel paling banyak memiliki pendidikan terakhir tamat SD dan hasil ini sesuai dengan penelitian yang dilakukan oleh Widayati dan Ulfania (2012). Menurut Widayati dan Ulfania (2012), pendidikan yang rendah dapat mempengaruhi kemampuan seseorang dalam menyerap 
informasi. ${ }^{[8]}$ Kurangnya informasi tersebut menyebabkan berkurangnya kewaspadaan seseorang terhadap suatu penyakit (Atmarita, 2004). [9]

Tingkat pengetahuan pada penelitian ini dinilai berdasarkan tiga tingkatan awal pengetahuan yaitu tahu, memahami, dan aplikasi. Pada level tahu dan memahami sebagian besar sampel memiliki nilai baik sedangkan pada level aplikasi sebagian sampel memiliki nilai sangat baik. Pada penelitian ini ditemukan beberapa sampel dimana pada level tahu memiliki nilai yang rendah, sedangkan pada level aplikasi memiliki nilai yang tinggi yang menandakan bahwa dimungkinkan beberapa sampel pada penelitian ini tidak melewati proses pengetahuan secara berurutan. Perbedaan tersebut sesuai dengan teori menurut Anderson dan Krathwohl (2010) yang menyatakan bahwa proses pengetahuan dapat dimulai dari level mana saja dan tidak harus selalu melewati level yang berurutan. [10]

Berdasarkan hasil penelitian diketahui bahwa sebagian besar sampel pada penelitian ini memiliki sikap yang cukup. Sikap berperan dalam bagaimana seseorang berperilaku dan mengambil keputusan dalam proses kesembuhannya. Selain itu, sikap positif yang dimiliki seseorang terhadap penyakitnya akan mengarah pada health seeking behavior yang positif pula sehingga harapannya dengan sikap positif tersebut semakin mendorong seseorang dalam usahanya menuntaskan pengobatan (Mweemba et al. 2008). [11]

Dari keseluruhan jumlah sampel, sebanyak 13 sampel pada penelitian ini memiliki tingkat kepatuhan minum obat yang tinggi. Berdasarkan hasil observasi oleh peneliti, tingkat kepatuhan yang tinggi tersebut disebabkan karena pasien cenderung merasa takut akan dampak yang ditimbulkan oleh ketidakteraturan minum obat.

Selain itu tingginya tingkat kepatuhan pasien juga dapat dipengaruhi oleh faktor penguat (reinfocing factor) berupa dukungan keluarga serta peran PMO ataupun faktor pemungkin (enabling factor) berupa ketersediaan sarana dan prasarana dalam pasilitas kesehatan (Lawrance Green dalam Notoatmodjo, 2010). [12]

Hasil uji korelasi antara pengetahuan terhadap sikap didapatkan hasil yang signifikan antara tingkat pengetahuan pada level tahu dengan $(\mathrm{p})$ sebesar 0,041. Sedangkan pada level memahami dan aplikasi dengan (p) sebesar 0,555 dan 0,375 secara berurutan. Berbeda dengan penelitian yang dilakukan oleh Dewi (2011) yang menggunakan kuesioner yang sama dengan penelitian ini, menunjukkan bahwa tidak terdapat hubungan yang signifikan pada ketiga level pengetahuan terhadap kepatuhan. [13]

Meski hasil penelitian ini didapatkan hasil yang tidak signifikan pada level memahami dan aplikasi, tetapi peneliti masih meyakini bahwa dengan memahami serta mengaplikasikan pengetahuannya dengan baik, hal tersebut akan mempengaruhi tingkat kepatuhan pasien. Sesuai pendapat menurut Notoatmodjo (2010) yang menyatakan bahwa pengetahuan atau kognitif merupakan hal yang sangat penting untuk terbentuknya suatu tindakan. [12] Pengetahuan tersebut dapat membantu individu untuk beradaptasi dengan penyakitnya, mencegah komplikasi dan mematuhi program terapi sehingga harapannya semakin tinggi tingkat pengetahuan yang dimiliki pasien tentang penyakit TB semakin tinggi pula tingkat kepatuhan penderita dalam mengkonsumsi obat TB Paru. 
Hasil uji korelasi antara sikap dan kepatuhan menunjukkan hasil yang tidak signifikan antara sikap terhadap kepatuhan dengan $\mathrm{p}=0,321$ dan $\mathrm{r}=$ 0,228 . Pada penelitian ini didapatkan sampel yang mempunyai sikap cukup sebagian besar memiliki tingkat kepatuhan yang tinggi. Sesuai dengan teori perubahan sikap dalam mematuhi anjuran oleh Kelman dalam Alhamda (2014), kemungkinan sampel yang memiliki sikap cukup tersebut masih berada dalam tahapan compliance atau identification. [14] Teori tersebut mengatakan bahwa pada tahap compliance individu mematuhi anjuran tanpa adanya kesadaran diri dan cenderung mematuhi anjuran karena takut akan hukuman atau sanksi yang akan didapat. Sedangkan pada tahap identification, biasanya kepatuhan yang timbul pada tahap ini terjadi karena individu merasa tertarik atau mengagumi tokoh tertentu sehingga ia ingin menirukan tindakannya tanpa memahami sepenuhnya arti dan manfaat dari tindakan tersebut. Sebaliknya pada tahapan terakhir yaitu internalization, seseorang yang berada pada tahap ini akan mematuhi anjuran karena mengetahui manfaat yang ia dapat dengan mematuhi anjuran tersebut.

\section{SIMPULAN DAN SARAN}

Dari hasil data dan pembahasan yang telah dijabarkan, kesimpulan pada penelitian ini adalah terdapat hubungan yang signifikan antara pengetahuan pada level tahu terhadap kepatuhan minum obat. Namun pada level memahami dan aplikasi tidak didapatkan hasil yang serupa. Selanjutnya, tidak didapatkan hasil yang signifikan pula antara sikap dan kepatuhan minum obat.
Secara teknis terdapat beberapa kendala yang dialami peneliti yang selanjutnya dapat dijadikan bahan pertimbangan oleh peneliti lain. Kendala utama yang dialami peneliti adalah dalam menemui sampel. Beberapa sampel tidak mengambil obat sesuai dengan jadwal sehingga peneliti harus mendatangi kediaman sampel secara satu-persatu dengan bantuan kader puskesmas. Harapan bagi peneliti selanjutnya perlu diadakan koordinasi dengan petugas puskesmas mengenai metode pengambilan obat agar memudahkan dalam menemui pasien. Selain itu, petlu diperhatikan pula dalam pemilihan kuesioner untuk mengukur kepatuhan karena pada penelitian ini kuesioner MMAS-8 membutuhkan recall yang dikhawatirkan dapat menjadi faktor bias.

\section{DAFTAR RUJUKAN}

[1] World Health Organization, 2015. Global Tuberculosis Report 2015. http://apps.who.int/iris/bitstrea $\mathrm{m} / 10665 / 191102 / 1 / 978924156$ 5059 eng.pdf. [Diakses pada 7 Sempember 2017].

[2] Yuni, I.D.A.M.A. 2016. Hubungan Fase Pengobatan TB dan Pengetahuan tentang MDR TB dengan Kepatuhan Pengobatan Pasien TB. Skripsi. Surabaya: Departemen Epidemiologi Kesehatan Masyarakat Universitas Airlangga.

[3] Nugroho, R. A. 2011. Studi Kualitatif Faktor yang Melatarbelakangi Drop Out Pengobatan Tuberkulosis Paru. Skripsi. Semarang: Jurusan Ilmu Kesehatan Masyarakat, Fakultas Ilmu Keolahragaan, Universitas Negeri Semarang. 
[4] Notoatmodjo, S. 2010. Ilmu Perilaku Kesehatan. Jakaarta: Rineka Cipta.

[5] Linda, D.O., 2012. Hubungan Karakteristik Klien Tuberkulosis dengan Pengetahuan tentang Multy Drugs Resisten Tuberkulosis (MDR TB) di Poli Paru Puskesmas Kecamatan Jagakarsa. Skripsi. Depok: Universitas Indonesia.

[6] Erawatyningsih. E. dan Purwanta, H. S. 2009. Faktor-Faktor Yang Mempengaruhi Ketidakpatuhan Berobat Penderita Tuberkulosis Paru. Berita Kedokteran Masyarakat. 25 (3): 117-124

[7] Kemenkes RI. 2011. Pedoman Nasional Penanggulangan Tuberkulosis. Kementrian Kesehatan Republik Indonesia.

[8] Widayati N, Ulfania N. Studi Deskriptif Faktor-Faktor Penyebab Default pada Penderita TB Paru Program Directly Observed Treadment Short Course (DOTS) di RSUD Batang tahun 2012. Skripsi. Batang: Program Studi Keperawatan STIKes Muhammadiyah Pekajangan; Agustus 2013.

[9] Atmarita. 2004. Analisis Situasi Gizi dan Kesehatan Masyarakat Jakarta: LIPI.
[10] Anderson, L. W. dan David R. Krathwohl. $2010 \quad$ Kerangka Landasan

untuk Pembelajaran, Pengajaran, dan Asesmen; Revisi Taksonomi Pendidikan Bloom, terjemahan Agung Prihantoro, (Yogyakarta: Pustaka Pelajar.

[11] Mweemba, P. Haruzivishe, C. Siziya, S. Chipino, P.J, Cristenson K, and Johansson E. 2008. Knowledge, Attitude, and Compliance with Tuberculosis Treatment, Lusaka, Zambia. Medical Journal of Zambia. 35 (4).

[12] Notoatmdjo, S. 2010. Promosi Kesehatan Teori dan Aplikasi. Jakarta: Rineka Cipta

[13] Dewi, P.M.S. 2011. Hubungan Pengetahuan dan Sikap Penderita TB Paru dengan Kepatuhan Minum Obat Anti Tuberkulosis. Skripsi. Surabaya: Fakultas Kesehatan Masyarakat Universitas Airlangga.

[14] Alhamda, S. 2014. Buku ajar Sosiologi Kesehatan. Yogyakarta: Deepublish 